\title{
Propionibacteria used as probiotics - A review
}

\author{
S Mantere-Alhonen \\ Department of Food Technology/Dairy Science, PBox 27, \\ 00014 University of Helsinki, Helsinki, Finland
}

\begin{abstract}
Summary - The investigation of probiotics has been very intensive during the last decades, concentrating mainly on lactic acid and bifidobacteria. But there is also clear evidence that propionibacteria have probiotic effects. The probiotic influence is based on the production of propionic acid, bacteriocins, vitamin $B_{12}$, better exploitation of fodder, growth stimulation of other beneficial bacteria and the ability to stay alive during gastric digestion. In Finland, large test series with piglets receiving Propionibacterium freudenreichii in their fodder have been performed. The growth promotant effect was significant and the fodder demand was clearly lower when compared with the control group. The bacterial concentration used was, on average, $2 \times 10^{9} \mathrm{cfu} / \mathrm{g}$ and the dose/animal $1-5 \mathrm{~g} / \mathrm{d}$. The mineral and trace element contents of a Propionibacterium freudenreichii-mass have also been studied. In other European countries, mixtures of propionibacteria and lactic acid/bifidobacteria have been used with positive results as probiotics for calves. Propionibacteria have also been investigated as human probiotics, especially in curing intestinal disorders of children and elderly people. The occurrence of lactic acid bacteria and propionibacteria in living food is very interesting as different kinds of this food type obviously act as probiotics. Thus, propionibacteria can be considered as potential probiotics requiring further research.
\end{abstract}

\section{propionibacteria / probiotics / growth promotion / Propionibacterium freudenreichii / living} food

Résumé - Bactéries propioniques utilisées comme probiotiques : revue. Durant les dernières décennies, la recherche de probiotiques a été très intense, principalement sur les bactéries lactiques et les bifidobactéries. Mais il est également évident que les bactéries propioniques ont des effets probiotiques. Leur activité probiotique est basée sur la production d'acide propionique, de bactériocines, de vitamine $B_{12}$, la meilleure utilisation des fourrages, la stimulation de la croissance des autres bactéries bénéfiques et la capacité à survivre au cours de la digestion gastrique. En Finlande, un test à grande échelle a été effectué sur des porcelets auxquels on incorporaitPropionibacterium freudenreichii à la nourriture. L'effet sur la promotion de la croissance était significatif et la demande de fourrage était nettement plus basse comparée au groupe contrôle. La concentration bactérienne utilisée était en moyenne de $2 \times 10^{9}$ ufc/g et la dose par animal de 1-5 g/jour. Les teneurs en minéraux et oligoéléments d'une biomasse de Propionibacterium freudenreichii ont également été étudiées. Dans d'autres pays européens, des mélanges de bactéries propioniques et lactiques/bifidobactéries ont été utilisés comme probiotiques pour les veaux, avec des résultats positifs. Les bactéries propioniques ont aussi été utilisées et examinées comme probiotiques chez l'homme, spécialement pour soigner les désordres intestinaux des enfants et des personnes âgées. La présence de bactéries lactiques et de bactéries 
propioniques dans les aliments vivants est très intéressante puisque plusieurs sortes d'aliments de ce type agissent manifestement comme probiotiques. Les bactéries propioniques peuvent donc être considérées comme des probiotiques potentiels nécessitant de plus amples recherches.

bactérie propionique / probiotique / promoteur de croissance / Propionibacterium freudenreichii / aliment vivant

\section{INTRODUCTION}

Propionibacteria strains originally classified in the genus Propionibacterium and its 4 species all come from cheese or other dairy products. Some have even been isolated from soil, silage, fermenting olives and the intestines of rats (Mantere-Alhonen, 1982; Balows et al, 1992). These bacteria form the group of "classical propionibacteria". The economic value of these propionibacteria of dairy origin derives from their important role in cheesemaking, especially of hard Swiss-type cheeses. Other industrial applications are in the production of propionic acid and vitamin $B_{12}$. A less studied characteristic is the bacteriocin production of species of the genus Propionibacterium. Only 3 bacteriocins have been identified from propionibacteria (Grinstead and Barefoot, 1992; Lyon and Glatz, 1993). This ability may be of importance in their action as probiotics.

During the last few decades, the investigation of probiotics has been very intensive, the emphasis being, however, primarily on lactic acid and bifidobacteria. Probiotics are health-promoting bacteria originating from the intestinal tract of humans or animals; they have to maintain their activity and high cell concentration during the passage through the intestines of the host. The probiotic effect is based on the production of beneficial metabolites and antimicrobial components, better exploitation of fodder, higher resistance to harmful bacteria, stabilization of the intestinal microflora as well as anticarcinogenic and anticholesterolemic influences.
Several experiments have shown that propionibacteria also possess probiotic characteristics when used alone or together with lactic acid and/or bifidobacteria. The most important factors associated with the probiotic effects are the production of propionic acid and minor organic acids, $\mathrm{CO}_{2}$, bacteriocins, vitamins as well as the ability of the propionibacteria to stay alive during digestion.

\section{PROPIONIBACTERIA AS GROWTH PROMOTORS}

The investigations concerning growth promotion by propionibacteria date mainly from the 1980s. The work done in Eastern Europe deals mostly with combined preparations of propionibacteria and lactic acid bacteria. Antipov and Subbotin (1980) used propionibacteria in combination with Lactobacillus acidophilus, $L$ delbrueckii ssp bulgaricus, Lactococcus lactis and different bifidobacteria for curing disorders of the digestive tract of calves, piglets and hens with good success. The bacterial concentration used was $4-6 \times 10^{9} \mathrm{cfu} / \mathrm{g}$. Tuikov et al (1980) as well as Vladimirov et al (1977) have had identical results with similar bacterial combinations. In 1991, Cerna et al invented a preparation called Proma, which is a blended culture of microorganisms including Lactobacillus plantarum, Enterococcus faecium, Lactococcus lactis and Propionibacterium freudenreichii. The concentration used was $2 \times 10^{8} \mathrm{cfu} / \mathrm{g}$. The daily feed intake of calves was slightly lower with Proma and the daily weight gain was clearly 
higher. Even after withdrawal of Proma, the calves continued to gain weight $11-22 \%$ faster than the control group. While studying a mixed culture of $L$ acidophilus and $P$ freudenreichii ssp shermanii, Liu and Moon (1982) observed that the growth rate as well as the amounts of lactic and propionic acid produced were higher than in multicultures, which could contribute to the mixed cultures' effect as a probiotic.

In Finland, a large test material of young piglets fed with different propionibacteria species was investigated. $P$ freudenreichii ssp shermanii was found to be the most effective probiotic of the propionibacteria studied (Mantere-Alhonen, 1982). This was the first time that the probiotic and growthpromoting effect of pure propionibacteria was studied and the results obtained were positive. The most extensive test, using 230 piglets, involved adding 1-5 g/d per animal of Propionibacterium freudenreichii-mass cultivated in a trypsin-treated whey + silage juice to normal fodder. At the end of the test, the piglets were 7 weeks old. According to our knowledge, this was the first time that pure propionibacteria were used as probiotics in order to achieve growth promotion in piglets. The propionibacteria concentration fed to the test animals was $2 \times 10^{9} \mathrm{cfu} / \mathrm{g}$. The weekly weight gain, fodder demand and general welfare of the piglets were observed. The difference between the propionibacteria and control groups was clear. In the propionibacteria groups, the weight gain was $9.2-14.5 \%$ higher and the fodder demand $7.2-46.1 \%$ lower than in the control groups. In addition, the piglets receiving propionibacteria had less diarrhoea. In bigger swine, the effect is even more evident (MantereAlhonen and Myllymäki, 1985). Because of the rather large test material, the positive results of the feeding experiments should be considered as statistically significant, and they prove the ability of propionibacteria to act as probiotics. Even though no colonization or adhesion of propionibacteria could be demonstrated in the intestines of the piglets, the presence of these beneficial bacteria in the intestines induces the effect. An in vitro digestion test has been done by Mantere-Alhonen (1983) in order to study the survival of Propionibacterium freudenreichii. No decrease in the concentration of $P$ freudenreichii could be observed during the test. This is an important characteristic for a probiotic microorganism.

The mineral contents in the cell mass of propioni-, bifido- and lactic acid bacteria have been studied by Vuorinen and Mantere-Alhonen (1982) and Mantere-Alhonen and Vuorinen (1989). Tentatively, it could be assumed that these minerals could contribute to the probiotic effect of these bacteria. In a Propionibacterium freudenreichii-mass, the concentrations (in $\mathrm{mg} / \mathrm{kg}$ ) of $\mathrm{Mn}$ (267), $\mathrm{Zn}$ (159), $\mathrm{Cu}(102)$ and $\mathrm{Fe}$ (535) are clearly higher than in the lactic acid and bifidobacteria masses tested.

The most recent investigations in Finland have dealt with feeding Wistar rats with combined preparations of propionibacteria, lactic acid and bifidobacteria in oat and rye diets (Ryhänen, thesis in preparation). This work has shown a positive influence on $\beta$ galactosidase and anticholesterolemic activity in the test animals fed the combined preparations mentioned previously.

\section{PROPIONIBACTERIA AS HUMAN PROBIOTICS}

In probiotic food products, propionibacteria are primarily combined with lactic acid and/or bifidobacteria. Most experiments have been concerned with curing intestinal disorders of children. Primarily Lactobacillus acidophilus was used in mixed culture with propionibacteria (Kornyeva, 1981; Nabukhotnuy et al, 1983; Sanigullina and Pawliuk, 1984). A question about the interaction and possible antagonistic effects between propionibacteria and lactic acid 
bacteria has been raised in this connection, with different viewpoints. According to Parker and Moon (1982), in most cases lactobacilli seem to dominate in the culture and even prevent the growth of propionibacteria. In mixed cultures, the growth rate of both genera and the production of acids and $\mathrm{CO}_{2}$ can be lower than in pure cultures. However, some Lactobacillus/Propionibacterium pairs have a beneficial effect on each others' growth. Thus, there are, in this respect, big differences between strains of both genera. Karasevich et al (1978) reported an antagonistic effect of the metabolites of propionibacteria to Lactobacillus acidophilus even in very dilute substrates. A recent study of Kaneko et al (1994) concerns the growth stimulation of Bifidobacterium adolescentis as produced by $P$ freudenreichii, a factor which could be significant when using these bacteria as probiotics. In mixed cultures, the growth of $B$ adolescentis increased from $3.7 \times 10^{6}$ cfu/ml, when grown alone, to $2.2 \times 10^{8}$ cfu/ $/ \mathrm{ml}$ and that of $P$ freudenreichii from 8.7 $\times 10^{7} \mathrm{cfu} / \mathrm{ml}$ to $4.7 \times 10^{8} \mathrm{cfu} / \mathrm{ml}$, respectively.

Mantere-Alhonen and Mäkinen (1986) attempted to develop a sour milk product containing Propionibacterium freudenreichii ssp shermanii and Lactobacillus acidophilus, with percentages of 3 to 1 . The product showed very good sensory properties, mild flavour, good consistency and good conservation quality. Its probiotic effect was tested with promising results in a small-scale trial with elderly hospital patients (unpublished data). A negative technological aspect is the long incubation time (4-5 d) that propionibacteria need before the combined incubation of $20 \mathrm{~h}$ can occur.

\section{PROPIONIBACTERIA IN LIVING FOOD}

Living food is any fresh uncooked food which includes vegetables, fruits, nuts, germinated seeds, beans and certain fermented items. Its therapeutic effect and influence on the human immune system has not yet been investigated thoroughly, but there is evidence of positive effects in the treatment of allergic, rheumatic and infectious diseases. In a study on the modification of faecal flora in rheumatoid arthritis patients by lactobacilli rich vegetarian food, Ryhänen et al (1993) showed that living food modifies the faecal flora in such a way as to cause less symptoms to the patients. The lactic acid bacteria contents in their gut was significantly higher than in the control group which ate a normal Western diet. This investigation led to more detailed analysis of the kinds of lactobacilli and propionibacteria which occur in living food, both fermented and nonfermented, as it was evident that these bacteria play a role in its beneficial effects (Mantere-Alhonen and Ryhänen, 1994). The following species of propionibacteria could be identified from 24 living food items: Propionibacterium acidi-propionici, $P$ freudenreichii ssp shermanii, $P$ jensenii and $P$ thoenii. The occurrence of $P$ acidi-propionici was apparent in fermented products, but nonfermented living food also contained propionibacteria, especially $P$ jensenii and $P$ thoenii. $P$ freudenreichii ssp shermanii occurred only in mushroom pickles. The presence of probiotic propionibacteria and lactobacilli could improve the significance of living food as a special "biological plus" in our nutrition.

\section{FUTURE ASPECTS}

The probiotic activity of propionibacteria has been clearly demonstrated in several studies. The effect is derived from the formation of propionic acid, together with some minor acids, of bacteriocins, vitamin $B_{12}$, as well as the presence of minerals, better exploitation of fodder and the ability to act as growth stimulators for other beneficial bacteria in the intestines. These effects are achieved 
even without colonization and adhesion in the bowels.

In the future, it would be interesting to conduct a more detailed study on the action of propionibacteria in the intestines as well as the interaction with other beneficial bacteria and also harmful bacteria in this environment. A better knowledge of the structure of propionibacteria cells and their physiological properties (eg, formation of bacteriocins, effect of bile salts, influence on the serum cholesterol levels, faecal enzyme activities and possible anticarcinogenic properties) would be of primary importance in order to understand their action as probiotics. The use of propionibacteria in combination with dietary fiber could be an interesting question to study.

The development of new dairy products containing propionibacteria is a field which deserves more investigation with possible applications to even other areas of food processing (eg, bakery industry). The occurrence of propionibacteria together with lactic acid bacteria in living food and subsequently their probiotic effect extends the use of these bacteria to new areas. In conclusion, the investigation of propionibacteria and their evident positive effects as probiotics should be continued in order to find solutions to the many still unanswered questions.

\section{REFERENCES}

Antipov VA, Subbotin VM (1980) Use of probiotics efficacy and prospects. From Dairy Sci Abstr 1982 , 44,8567

Balows A, Trüper HG, Dworkin M, Harder W, Schleifer $\mathrm{KH}$ (1992) The Procaryotes. Springer Verlag, New York, Berlin

Cerna B, Cerny M, Betkova H, Patricny P, Soch M, Opatrna I (1991) Effect of the Proma probiotics on calves. From Dairy Sci Abstr 55, 1735

Grinstead DA, Barefoot SF (1992) Jenseniin G, a heatstable bacteriocin produced by Propionibacterium jensenii P126. Appl Environ Microbiol 58, 215-220
Kaneko T, Mori H, Iwata M, Meguro S (1994) Growth stimulator for bifidobacteria produced by Propionibacterium freudenreichii and several intestinal bacteria. J Dairy Sci 77, 393-404

Karasevich EK, Marjenko VG, Zelkova NT (1978) Effect of metabolites of propionic acid bacteria on Lactobacillus acidophilus. From Dairy Sci Abstr 1980, 42, 7474

Kornyeva VV (1981) Establishment of propionic acid bacteria in the intestine of intants given propioniacidophilus milk. From Dairy Sci Abstr 1982, 44, 420

Liu JAP, Moon NJ (1982) Commensalistic interaction between Lactobacillus acidophilus and Propionibacterium shermanii. Appl Environ Microbiol 43, 715722

Lyon WA, Glatz BA (1993) Isolation and purification of propionicin PLG-1, a bacteriocin produced by a strain of Propionibacterium thoenii. Appl Environ Microbiol $59,83-88$

Mantere-Alhonen S (1982) Die Propionibakterien der Molkereindustrie als Darmkanalmikroben. Meijeritiet Aikak 40, 95 S

Mantere-Alhonen S (1983) On the survival of a Propionibacterium freudenreichil-culture during in vitro gastric digestion. Meijeritiet Aikak 41, 19-23

Mantere-Alhonen S, Myllymäki H (1985) Meijeri- teollisuuden propionibakteerien massantuottaminen ja ruokinnalliset sovellukset. Elintarvikeylioppilas 1, 1416

Mantere-Alhonen S, Măkinen E (1986) A new sour milk product containing Propionibacterium freudenreichii and Lactobacillus acidophilus. Meijeritiet Aikak $40,49-58$

Mantere-Alhonen S, Vuorinen A (1989) Mineral elements in the cell mass of lactic acid and bifidobacteria. Milchwissenschaft 44, 758-760

Mantere-Alhonen S, Ryhänen EL (1994) Lactobacilli and propionibacteria in living food. Microbiol Aliments Nutr 12, 399-405

Nabukhotnyi TK, Cherevko SA, Sanigullina FI, Grushko Al (1983) Use of adapted propioni-acidophilic "Malyutka" and "Malyush" formulas on complex treatment of acute gastrointestinal diseases of infants. From Dairy Sci Abstr 1985, 47, 2122

Parker JA, Moon NJ (1982) Interactions of Lactobacillus and Propionibacterium in mixed culture. J Food Prot 45, 326-330

Ryhänen EL, Mantere-Alhonen S, Nenonen M, Hänninen O (1993) Modification of faecal flora in rheumatoid arthritis patients by lactobacilli rich vegetarian diet. Milchwissenschaft 48, 255-259

Ryhänen EL Lactic acid, bifido- and propionibacteria and dietary fiber as health promoting factors in rats. (Thesis in preparation) 
Sanigullina FI, Pawliuk WP (1984) Eine experimentelle Beurteilung der biologischen Wertigkeit der Propionsäure-Acidophilus-Nährmittel "Malyutka" und "Malyush". From Mi 1985, 585,4,88,17

Tuikov R, Kristova M, Rizvanov K, Vladimirov I (1980) Early weaning calves using a milk additive and a preparation of freeze-dried bacteria. From Dairy Sci Abstr 1982, 44,1689
Vladimirov I, Rizvanov K, Vasilev A, Kenov P (1977) Tests on replacement of antibiotics in sucking calf feeding by a freeze-dried preparation of bacteria. From Dairy Sci Abstr 40, 2118

Vuorinen A, Mantere-Alhonen S (1982) On trace elements in Propionibacterium freudenreichii-mass. Meijeritiet Aikak 40, 283-290 